\title{
Molecular Detection of Enterotoxigenic E. coli in raw Milk and Milk Products
}

\author{
W.F. Amin ${ }^{*}$, E.H. Ahmed ${ }^{2}$, M.S. Embarak ${ }^{2}$, U.H. Abo-Shama ${ }^{3}$, \\ A.G. Thabit ${ }^{2}$ and S.Y. Ismail ${ }^{2}$ \\ ${ }^{1}$ Department of Food Hygiene, Faculty of Veterinary Medicine, Assiut University, Egypt \\ 2 Department of Microbiology and Immunology, Faculty of Medicine, Assiut University, Egypt \\ ${ }^{3}$ Microbiology and Immunology Department, Faculty of Veterinary Medicine, \\ Sohag University, Egypt \\ *Corresponding author
}

Keywords

Milk, Cheese, E. coli, ETEC, PCR.

Article Info

Accepted:

10 September 2017

Available Online:

10 November 2017

\section{A B S T R A C T}

This study aimed to determine the incidence of $E$. coli in raw milk and cheese, in addition to isolate and identify Enterotoxigenic E. coli. The existence of heat stable toxin (STh) and heat labile toxin (LT) genes were determined in the isolated strains. This study included 350 samples of raw milk and cheese samples. Different media were used to isolate E. coli and different biochemical tests were used for identification. $E$. coli was detected in $61.4 \%$ of samples. They were tested for the presence of STh and LT genes by PCR. ETEC was detected in $3.7 \%$ of E. coli isolates. Only one strain from milk of street samples that found to harbor STh gene. Seven strains were detected in Kareish cheese including two strains harbor LT gene and five strains harbor STh gene.

\section{Introduction}

Escherichia coli is an inhabitant of the intestinal tract of animals and humans (Wetzel, 2005). Six different groups of pathogenic E. coli strains exist that harbor various virulence factors which enable them to cause diarrheal disease; enterotoxigenic $E$. coli (ETEC), enteropathogenic E. coli (EPEC), enterohemorrhagic E. coli (EHEC), enteroaggregative E. coli (EAEC), enteroinvasive $E$. coli (EIEC), and diffusely adherent $E$. coli (DAEC) (Kaper et al., 2004). A wide variety of food has been implicated as a vehicle of $E$. coli infection including milk.
Most illness has been associated with eating undercooked and contaminated food also drinking unpasteurized milk (Altalhi and Hassan, 2009).

ETEC strains are emerging cause of food borne outbreaks, and have the ability to produce heat-stable and heat-labile enterotoxins. They are frequently associated with traveler's diarrhea and diarrhea in children (Wetzel, 2005). Diarrhea is watery and typically has an abrupt onset with an incubation period of 14 - 50 hours. Vomiting 
is also a symptom but not fever. Mild to severe loss of fluids and electrolytes results in dehydration. More severe cases may require hospitalization (Wenneras and Erling, 2004; Qadri et al., 2005).

In developing countries, ETEC can be isolated from both symptomatic and asymptomatic carriers, with significant mortality rates in children (Qadri et al., 2005). In rural Egypt, a study showed that $84 \%$ of children under the age of 3 had at least one ETEC-related episode of diarrhea. The authors estimated that there were approximately 1.5 episodes/child/year related to ETEC (Rao et al., 2003). The ETEC pathogenesis suggests that the organism colonize the small intestine by colonization factors, followed by the elaboration of heatstable (ST) and/or heat-labile enterotoxin (LT). These virulence factors allow the organisms to readily colonize the small intestine and thus cause diarrhea (Qadri et al., 2005). Coli surface antigen 6 CS6 is one of the most prevalent ETEC CS observed worldwide (Lapa et al., 2008).

Since milk has almost neutral $\mathrm{pH}$ with high water content and a variety of nutrients, it represents an ideal substrate for microbial growth (Jay et al., 2005). Milk contamination is usually associated with handling of milk by man and fecal contamination (Karns et al., 2007). Presence of pathogenic bacteria in milk is of public health concern. Numbers of microorganisms including Escherichia coli can contaminate milk and milk products (Oliver et al., 2005).

This work aimed to determine the incidence of $E$. coli in raw milk, Damietta and Kareish cheeses. Also, determine the incidence of enterotoxigenic $E$. coli by molecular detection of stable toxin (ST) and /or labile toxin (LT).

\section{Materials and Methods}

\section{Collection of samples}

A total of 350 random samples of raw milk and some milk products were collected from different sources in Assiut city. They were 200 samples of raw milk from farms, dairy shops and street vendors and 150 cheese samples (100 Damietta cheese and 50 Kareish cheese) from markets, vendors and super markets. Samples were transferred immediately in an ice box to the laboratory and stored at $4{ }^{\circ} \mathrm{C}$ until examined within 24 hours.

\section{Preparation of samples}

Each milk sample was tested for detection of heat treatment by Storch test according to (Lampert, 1975) to exclude all heat treated milk samples.

Ten ml of milk sample was centrifuged for 20 minutes at 3000 r.p.m then the cream and supernatant were discarded. For cheese samples, $25 \mathrm{~g}$ of each sample was blended with $225 \mathrm{ml}$ of nutrient broth (Difco) for 2 min. using a Stomacher lab blender, and then samples were incubated at $37^{\circ} \mathrm{C}$ for $24 \mathrm{~h}$ (Read et al., 1990).

Enrichment of samples (Quinto and Cepeda, 1997)

One $\mathrm{ml}$ of prepared milk and cheese samples was mixed with $9 \mathrm{ml}$ MacConkey's broth (Oxoid, UK) and incubated for $24 \mathrm{~h}$ at $37^{\circ} \mathrm{C}$.

\section{Selective plating (Cheesbrough, 2004)}

A loopful of the incubated broth was streaked on MacConkey's agar and E.M.B. agar media. Plates were aerobically incubated at $37^{\circ} \mathrm{C}$ for $24 \mathrm{~h}$. 


\section{Identification of $E$. coli isolates}

Gram stained films of suspected E. coli colonies showing Gram negative, nonspore forming bacilli. Biochemical tests were used to confirm E. coli isolates. All E. coli isolates were positive for catalase, indole, and methyl red and negative for oxidase, urease, citrate and Voges-Proskauer. Sugar fermentation using triple sugar iron indicated acid slant and butt and gas production (Collee et al., 1996).

\section{Identification of ETEC by PCR for detection of ST, LT genes}

\section{DNA extraction (Hassan and Elmalt, 2008)}

Bacterial DNA was extracted following cultivation in trypticase soy agar (TSAScharlau, Spain.) at $37^{\circ} \mathrm{C}$. A colony was suspended in $100 \mu \mathrm{l}$ sterile distilled water and the suspension was boiled for 10 mins. Then centrifugation was done and the supernatant was used as a template for PCR and stored at $-20^{\circ} \mathrm{C}$ until use.

\section{DNA amplification}

STh and LT genes were amplified separately using primers described previously (Vidal et al., 2009 and Nada et al., 2010). Primers were purchased from Invitrogen, USA. The used primers sequences are described in Table 1.

Table.1 PCR was carried out in $50 \mu$ l reaction volume using master mix (Koma Biotech Inc., Korea)

\begin{tabular}{|l|l|c|}
\hline \multirow{2}{*}{ Gene } & Primer sequence 5'-3' & $\begin{array}{l}\text { Product } \\
\text { Band size (bp) }\end{array}$ \\
\hline \multirow{2}{*}{ LT } & $\begin{array}{l}\text { sense- } \\
\text { CATAATGAGTACTTCGATAGAGGAAC- }\end{array}$ & \\
\cline { 2 - 3 } & $\begin{array}{l}\text { antisense- } \\
\text { GAAACCTGCTAATCTGTAACCATCC- }\end{array}$ & \\
\hline \multirow{2}{*}{ STh } & $\begin{array}{l}\text { sense- } \\
\text { TTCTTTCTGTATTGTCTTTTTCACC- }\end{array}$ & \\
\cline { 2 - 3 } & $\begin{array}{l}\text { antisense- } \\
\text { TAATAGCACCCGGTACAAGCAG- }\end{array}$ & \\
\hline
\end{tabular}

PCR thermal cycler (Bio Rad T100, USA) was used with initial denaturation step at $95^{\circ} \mathrm{C}$ for $2 \mathrm{~min}$., followed by 30 cycles of $95^{\circ} \mathrm{C}$ for $1 \mathrm{~min}$., annealing temperature of $58^{\circ} \mathrm{C}$ for $30 \mathrm{sec}$. and elongation for $1 \mathrm{~min}$. at $72^{\circ} \mathrm{C}$ and a final extension step at $72^{\circ} \mathrm{C}$ for 10 min. Ten $\mu$ from each PCR product were examined by electrophoresis in $1.5 \%$ agarose gel stained with ethidium bromide under U.V light.

\section{Statistical analysis}

Statistical analysis was performed using SPSS version 16.0. Data was presented as numbers and percentages. Chi-square test was used to compare qualitative variables between groups. P-value $<0.05$ was considered statistically significant.

\section{Results and Discussion}

Enterotoxigenic Escherichia coli (ETEC) is causing approximately 280-400 million diarrheal episodes in children under the age of five every year. It has been recognized as the most common cause of infectious diarrhea in infants and young children in developing countries (Wennerås and Erling, 2004). Also, the elderly are also susceptible to ETEC infections requiring hospitalization (Faruque et al., 2004). The infection is caused by ingestion of contaminated food and water. Food can be contaminated by infected food handlers or asymptomatic carriers or when using untreated water (Croxen et al., 2013).

Results recorded in Table 2 revealed that $E$. coli was isolated from $62 \%$ of total raw milk samples; $59 \%$ of dairy farms, $62 \%$ of dairy shops and $68 \%$ of street vendors. Lower results were mentioned by Kumar and Prasad (2010) who found that the highest contamination was recorded in milk from vendors $(26 \%)$ followed by dairy farm $(20 \%)$. In addition, lower results were reported by Bali et al., (2013) (32.5\%), Rashid et al., (2013) (33.96\%), Virpari et al., (2013) (52\%) and El nahas et al., (2015) (55\%). Compatible results were reported by, Ali and Abdelgadir 
(2011) (63\%) and Chye et al., (2004) (65\%), but higher results was found by Hassan and Elmalt, (2008) (76.0\%) and Ibrahim et al., (2015a) (100\%).

High incidences of $E$. coli in the examined raw milk samples indicated neglected sanitary control in handling of milk and possibly fecal contamination. Microorganisms may gain entry into raw milk from the dairy animals experiencing subclinical or clinical mastitis, or from fecal contamination, particularly around the teats, and from the farm environment particularly the water source and utensils used for the storage of milk on the farm or during transportation (Ombarak and Elbagory, 2015).

Regarding the results in Table 3, E. coli was isolated from $60.7 \%$ of cheese samples; $36 \%$ of Damietta cheese and $73 \%$ of Kareish cheese. Many investigators mentioned lower incidence of $E$. coli in Kareish cheese as Virpari et al., (2013) (28\%) and El nahas et al., (2015) (50\%). Dissimilar higher results were reported by Paneto et al., (2007) (96\%), Najand and Ghanbarpour (2007) $(98.7 \%)$ and Ibrahim et al., (2015a) (100\%).
Concerning Damietta cheese, rare research was done. However, lower results were reported by Ahmed, (2012) (30.48\%) and Sharaf et al., (2014) (7\%). But higher results were reported by Ibrahim et al., (2015a) (80\%) and Ibrahim et al., (2015b) (40\%).

E. coli was recovered from $61.4 \%$ of the total examined milk and cheese samples (Table 4). Milk can be easily contaminated by infected food handlers who practice poor personal hygiene or by water containing human discharge. Therefore, water must be safe and practically free from pathogens. Also contamination of milk products is largely due to processing, handling, and unhygienic conditions and detection of E. coli in milk often reflects faecal contamination (El nahas et al., 2015). Contamination of cheese with microorganisms may originate from many sources. Such sources during cheese production might be: starter culture, brine, floor and packaging material, cheese vat, cheese cloth and curd cutting knife, cold room and production room air (Sharaf et al., 2014).

Table.2 Incidence of $E$. coli in raw milk samples

\begin{tabular}{|c|c|c|c|c|}
\hline \multirow{2}{*}{$\begin{array}{c}\text { Examined raw milk } \\
\text { samples }\end{array}$} & \multirow{2}{*}{ No. of examined samples } & \multicolumn{2}{|c|}{ Positive samples } & \multirow{2}{*}{ P value } \\
\cline { 3 - 4 } & & No. & $\mathbf{\%}$ & \\
\hline Dairy farms & 100 & 59 & 59 & \multirow{2}{*}{$0.574^{*}$} \\
\hline Dairy shops & 50 & 31 & 62 & \\
\hline Street vendors & 50 & 34 & 68 & \\
\hline Total & $\mathbf{2 0 0}$ & $\mathbf{1 2 4}$ & $\mathbf{6 2}$ & \\
\hline
\end{tabular}

*: No statistically significant difference ( $p>0.05)$

Table.3 Incidence of $E$. coli in cheese samples

\begin{tabular}{|c|c|c|c|c|}
\hline \multirow{2}{*}{ Examined cheese samples } & \multirow{2}{*}{ No. of examined samples } & \multicolumn{2}{|c|}{ Positive samples } & \multirow{2}{*}{$P$ value } \\
\hline & & No. & $\%$ & \\
\hline Damietta cheese & 50 & 18 & 36 & \multirow{3}{*}{$0.001 *$} \\
\hline Kareish cheese & 100 & 73 & 73 & \\
\hline Total & 150 & 91 & 60.7 & \\
\hline
\end{tabular}

* Statistically significant difference $(\mathrm{p}<0.01)$ 
Table.4 Incidence of E. coli in raw milk, Damietta and Kareish cheese

\begin{tabular}{|c|c|c|c|}
\hline Examined cheese & No. of examined & \multicolumn{2}{|c|}{ Positive samples } \\
\cline { 3 - 4 } samples & samples & No. & $\mathbf{\%}$ \\
\hline Raw milk & 200 & 124 & 62 \\
\hline Damietta cheese & 50 & 18 & 36 \\
\hline Kareish cheese & 100 & 73 & 73 \\
\hline Total & $\mathbf{3 5 0}$ & $\mathbf{2 1 5}$ & $\mathbf{6 1 . 4}$ \\
\hline
\end{tabular}

Table.5 Detection of STh gene in E. coli isolates

\begin{tabular}{|c|c|c|c|c|}
\hline \multirow{2}{*}{ Examined samples } & \multirow{2}{*}{$\begin{array}{c}\text { No. of positive E. coli } \\
\text { samples }\end{array}$} & \multicolumn{2}{c|}{ STh } \\
\cline { 3 - 5 } & & 59 & No. & $\%$ \\
\hline \multirow{4}{*}{ Raw milk } & Dairy farms & 31 & - & - \\
\cline { 2 - 5 } & Dairy shops & 34 & 1 & - \\
\cline { 2 - 5 } & Street vendors & 124 & 1 & 0.9 \\
\cline { 2 - 5 } & Total & 18 & - & - \\
\hline \multirow{3}{*}{ Cheese } & Damietta cheese & 73 & 5 & 6.8 \\
\cline { 2 - 5 } & Kareish cheese & 91 & 5 & 5.5 \\
\cline { 2 - 6 } & Total & $\mathbf{2 1 5}$ & $\mathbf{6}$ & $\mathbf{2 . 8}$ \\
\hline
\end{tabular}

Table.6 Detection of LT gene in E. coli isolates

\begin{tabular}{|c|c|c|c|c|}
\hline \multirow{2}{*}{\multicolumn{2}{|c|}{ Examined samples }} & \multirow{2}{*}{$\begin{array}{l}\text { No. of positive } \\
\text { E. coli samples }\end{array}$} & \multicolumn{2}{|c|}{ LT } \\
\hline & & & No. & $\%$ \\
\hline \multirow{4}{*}{ Raw milk } & Dairy farms & 59 & - & - \\
\hline & Dairy shops & 31 & - & - \\
\hline & Street vendors & 34 & - & - \\
\hline & Total & 124 & - & - \\
\hline \multirow{3}{*}{ Cheese } & Damietta cheese & 18 & - & - \\
\hline & Kareish cheese & 73 & 2 & 2.7 \\
\hline & Total & 91 & 2 & 2.2 \\
\hline \multicolumn{2}{|c|}{ Total } & 215 & 2 & 0.93 \\
\hline
\end{tabular}

Table.7 Incidence of ETEC among E. coli isolates

\begin{tabular}{|c|c|c|c|c|}
\hline \multirow{2}{*}{$\begin{array}{c}\text { Examined raw } \\
\text { milk samples }\end{array}$} & No. of positive E. coli & \multicolumn{2}{|c|}{ Total ETEC } & \multirow{2}{*}{ P value } \\
\cline { 3 - 4 } samples & 124 & No. & \% & \\
\hline Raw milk & 18 & 1 & 0.9 & \multirow{2}{*}{$0.028^{*}$} \\
\hline Damietta cheese & 73 & - & - & \\
\hline Kareish cheese & $\mathbf{2 1 5}$ & 7 & 9.6 & \\
\hline Total & & $\mathbf{8}$ & $\mathbf{3 . 7}$ & \\
\hline
\end{tabular}

*Statistically significant difference $(\mathrm{p}<0.05)$ 
Fig.1 Agarose gel electrophoresis of amplified STh gene in positive E.coli (193 bp)

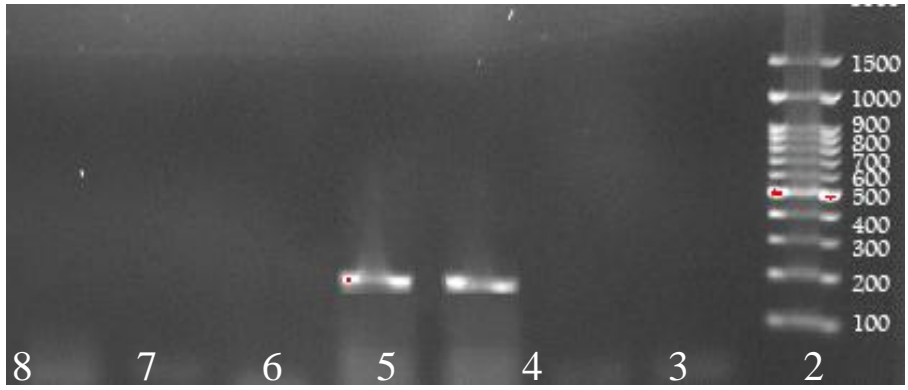

Lane 1: DNA marker, Lane 4, 5: positive STh E. coli

Fig.2 Agarose gel electrophoresis of amplified LT gene in positive E.coli (402 bp)

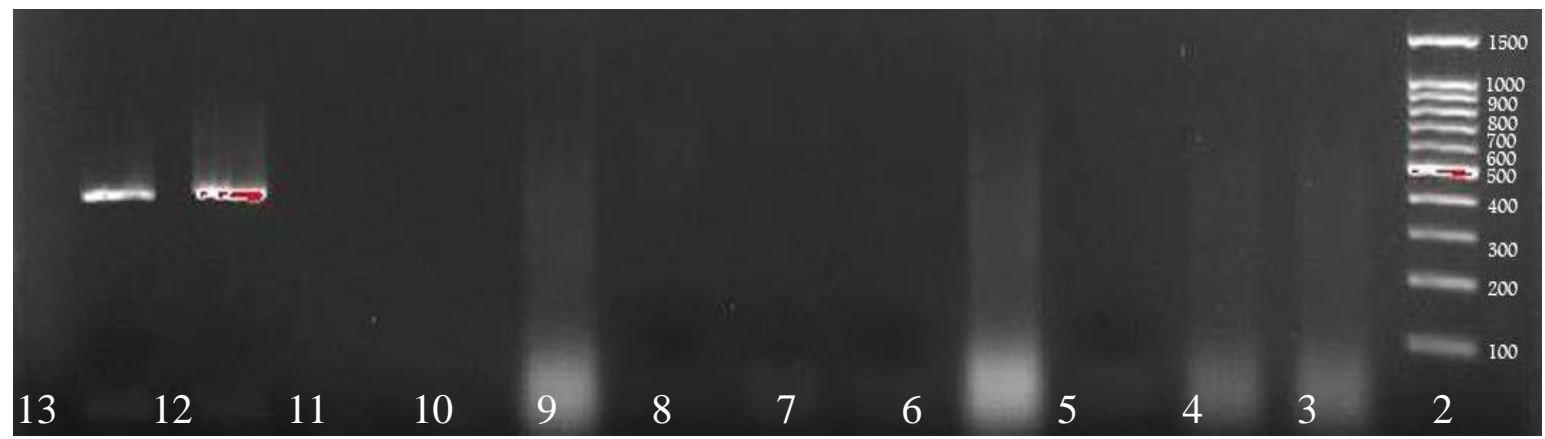

Lane 1: DNA marker, Lane 12 \&13: positive LT E. coli.

Results clearly indicated that microbial quality and safety of raw milk, Damietta and Kareish cheese was unsafe. The presence of fecal indicator organism not only indicates the poor hygiene but also may be pathogenic itself.

ETEC strains are classified based on their expression of enterotoxins either heat labile toxin (LT), heat stable toxin (ST) or both (Nicklasson, 2008). STh has been reported to cause diarrhea in children as well as in adult travelers to different geographical areas (Bölin et al., 2006). It is important to note that the levels of production of LT vary among different strains. Therefore, the regulation of LT production may occur differently in individual ETEC isolates (Mudrak and Kuehn, 2010). ETEC detection is reliant on detection of the enterotoxins LT and/or ST. Detection of both toxins is done by PCR based techniques. The PCR targets include the genes encoding LT and ST (O'Sullivan et al., 2007).

ETEC were detected in $3.7 \%$ of all milk and cheese samples. Only one isolate of E. coli from raw milk harbored STh gene so the incidence of ETEC in milk was $0.9 \%$. Two E. coli isolates of Kareish cheese had LT gene, while five had STh gene only, so ETEC were $9.6 \%$ of $E$. coli isolates.

Compatible results to the present work was found by many investigators as Bonyadian et al., (2014) who reported 1.66\% LT and STb in milk and cheese but none of the strains harbored the STa gene. Also El nahas et al., (2015) reported 27.27\% ETEC in milk samples and $15 \%$ in Kareish cheese. There was a significant difference between percentages of ETEC in raw milk, Damietta and Kareish cheese as shown in Table 7. ETEC were highly detected in Kareish cheese 
then raw milk but was not detected in Damietta cheese.

STh gene was detected in one $E$. coli isolate of raw milk samples that collected from street vendors also, it was detected in five $E$. coli isolates from Kareish cheese but it was not detected in Damietta cheese (Figure 1). According to the PCR of STh gene, it was found in $3.8 \%$ of the isolates from street vendors raw milk samples that represented 0.9 $\%$ of the total raw milk samples. In Kareish cheese, STh was detected in $6.8 \%$ of $E$. coli isolates but was not detected in Damietta cheese (Table 5). It is obvious that Kareish cheese represented a high level of contamination, hence a large source of infection. Results recorded in Table 6 and Figure 2 showed that LT gene was not detected in any of the isolates from raw milk samples and Damietta cheese but it was detected in two isolates $(2.7 \%)$ from Kareish cheese.

The proportions of ST-only, ST/LT, and LTonly strains vary between different studies and geographical areas. Roughly one third of all ETEC strains isolated globally have been reported to be ST- only strains, one third ST/LT and one third LT-only strains (Qadri et al., 2005). In other studies the ST-only strains have been reported to constitute up to $50 \%$ of the strains. ST-positive ETEC strains are commonly associated with diarrhea and found to be major contributor to infantile diarrhea and associated with an increased risk of death (Qadri et al., 2007).

This study indicated high contamination of milk and cheese especially Kareish cheese that is considered a public health threat. It is very important to apply standard sanitary measures to reduce contamination and infection and aware people around the importance of hygienic condition. Also, it is necessary to apply strict hygienic measures during milking and cheese production to minimize the contamination with such pathogen.

\section{References}

Ahmed, E.G.H. 2012. Microbiological evaluation of soft cheeses sold in Beni-Suef markets. M.V.Sc. Thesis, Fac. Vet. Med., Cairo Univ., Beni-Suef branch.

Ali, A.A. and Abdelgadir, W.S. 2011. Incidence of Escherichia coli in raw cow's milk in Khartoum state. British Journal of Dairy Science, 2, 23-26.

Altalhi, A.D. and Hassan, S.A. 2009. Bacterial quality of raw milk investigated by Escherichia coli and isolates analysis for specific virulence-gene markers. Food control, 20, 913-917.

Bali, O.S., Lajnef, R., Felfoul, I., Attia, H. and Ayadi, M.A. 2013. Detection of Escherichia coli in unpasteurized raw milk. International Journal of Agriculture and Food Science, 3.

Bölin, I., Wiklund, G., Qadri, F., Torres, O., Bourgeois, A.L., Savarino, S. and Svennerholm, A.M. 2006. Enterotoxigenic Escherichia coli with STh and STp genotypes is associated with diarrhea both in children in areas of endemicity and in travelers. Journal of clinical microbiology, 44, 3872-3877.

Bonyadian, M., Moshtaghi, H. and Taheri, M.A. 2014. Molecular characterization and antibiotic resistance of enterotoxigenic and entero-aggregative Escherichia coli isolated from raw milk and unpasteurized cheeses, Veterinary research forum: an international quarterly journal. Faculty of Veterinary Medicine, Urmia University, Urmia, Iran, p. 29.

Cheesbrough, M. 2004. Morphology and characterization of $E$. coli and S. aureus. District Laboratory practice in tropical countries part II. Cambridge University, 157-179.

Chye, F.Y., Abdullah, A. and Ayob, M.K. 2004. Bacteriological quality and safety of raw milk in Malaysia. Food microbiology, 21, 535-541. 
Collee, J., Fraser, A., Marmion, B. and Simmons, A. 1996. Mackie and McCartney. Practical Medical Microbiology, 14.

Croxen, M.A., Law, R.J., Scholz, R., Keeney, K.M., Wlodarska, M. and Finlay, B.B. 2013. Recent advances in understanding enteric pathogenic Escherichia coli. Clinical microbiology reviews, 26, 822-880.

El nahas, A., Mohamed, $\mathrm{H}$. and El barbary, $\mathrm{H}$. 2015. Incidence of E. coli in raw milk and its products. Food control DepartmentFaculty of Veterinary Medicine. Benha University. Benha veterinary medical journal, 29(1):112- 117.

Faruque, A.S., Malek, M.A., Khan, A.I., Huq, S., Salam, M.A. and Sack, D.A. 2004. Diarrhoea in elderly people: aetiology, and clinical characteristics. Scandinavian journal of infectious diseases, 36, 204-208.

Hassan, S. and Elmalt, L. 2008. Informally raw milk and Kareish cheese investigation on the occurrence of toxigenic Escherichia coli in Qena city, Egypt with emphasis on molecular characterization. Ass. Univ. Bull. Environ. Res, 11, 35-42.

Ibrahim, G.A., Sharaf, O.M. and El-Khalek, A.B.A. 2015a. Microbiological Quality of Commercial Raw Milk, Domiati Cheese and Kareish Cheese. Sciences, 5, 171-176.

Ibrahim, J.I., Salama, E., Saad, A. and Helmy, A.A. 2015b. Microbial Quality of Some Dairy Products in Ismailia City. $2^{\text {nd }}$ Conference of Food Safety, Suez Canal University, Faculty of Veterinary Medicine, Volume I Page 14-21.

Jay J.M., Loessner M.J. and Golden D.A. 2005. Modern food microbiology. 7th edition. Springer Science, New York.

Kaper, J.B., Nataro, J.P. and Mobley, H.L. 2004. Pathogenic Escherichia coli. Nature Reviews Microbiology, 2, 123-140.

Karns, J.S., Van Kessel, J.S., McClusky, B.J. and Perdue, M.L. 2007. Incidence of Escherichia coli $\mathrm{O} 157: \mathrm{H} 7 \quad$ and $E$. coli virulence factors in US bulk tank milk as determined by polymerase chain reaction. Journal of Dairy Science, 90, 3212-3219.

Kumar, R. and Prasad, A. 2010. Detection of E. coli and Staphylococcus in Milk and Milk
Products in and around Pantnagar. Pakistan Journal of Nutrition, 1, 151-152.

Lampert, L.M. 1975. Modern Dairy Products. 3rd Ed., Chemical Publishing Co., Inc., New York, USA.

Lapa, J.A., Sincock, S.A., Ananthakrishnan, M., Porter, C.K., Cassels, F.J., Brinkley, C., Hall, E.R., van Hamont, J., Gramling, J.D. and Carpenter, C.M. 2008. Randomized clinical trial assessing the safety and immunogenicity of oral microencapsulated enterotoxigenic Escherichia coli surface antigen 6 with or without heat-labile enterotoxin with mutation R192G. Clinical and Vaccine Immunology, 15, 1222-1228.

Mudrak, B. and Kuehn, M.J. 2010. Heat-labile enterotoxin: beyond G M1 binding. Toxins 2, 1445-1470.

Nada, R.A., Shaheen, H.I., Touni, I., Fahmy, D., Armstrong, A.W., Weiner, M. and Klena, J.D. 2010. Design and validation of a multiplex polymerase chain reaction for the identification of enterotoxigenic Escherichia coli and associated colonization factor antigens. Diagnostic microbiology and infectious disease, 67, 134-142.

Najand, L. M. and Ghanbarpour, R. 2006. A study on enteropathogenic Escherichia coli isolated from domestic Iranian soft cheese. Vet. Arhiv, 76 (6): 531-536.

Nicklasson, M. 2008. Studies on the expression and regulation of enterotoxins and colonization factors in enterotoxigenic Escherichia coli (ETEC). Inst of Biomedicine. Dept of Medical Microbiology and Immunology, $\mathrm{PhD}$ thesis.

O’Sullivan, J., Bolton, D., Duffy, G., Baylis, C., Tozzoli, R., Wasteson, Y. and Lofdahl, S. 2007. Methods for detection and molecular characterisation of pathogenic Escherichia coli. Pathogenic Escherichia coli Network CO-ORDINATION ACTION FOOD-CT2006-036256.

Oliver, S.P., Jayarao, B.M. and Almeida, R.A. 2005. Foodborne pathogens in milk and the dairy farm environment: food safety and public health implications. Foodbourne Pathogens \& Disease, 2, 115-129.

Ombarak, R.A. and Elbagory, A.M. 2014. Bacteriological quality and saftey of raw 
camel milk in Egypt. Egyptian J. Dairy Sci., 42: 95-103.

Paneto, B., Schocken-Iturrino, R., Macedo, C., Santo, E. and Marin, J. 2007. Occurrence of toxigenic Escherichia coli in raw milk cheese in Brazil. Arquivo Brasileiro de Medicina Veterinária e Zootecnia 59, 508512.

Qadri, F., Saha, A., Ahmed, T., Al Tarique, A., Begum, Y.A. and Svennerholm, A.M. 2007. Disease burden due to enterotoxigenic Escherichia coli in the first 2 years of life in an urban community in Bangladesh. Infection and immunity, 75, 3961-3968.

Qadri, F., Svennerholm, A.-M., Faruque, A. and Sack, R.B. 2005. Enterotoxigenic Escherichia coli in developing countries: epidemiology, microbiology, clinical features, treatment, and prevention. Clinical microbiology reviews, 18, 465-483.

Quinto, E. and Cepeda, A. 1997. Incidence of toxigenic Escherichia coli in soft cheese made with raw or pasteurized milk. Letters in applied microbiology, 24, 291-295.

Rao, M.R., Abu-Elyazeed, R., Savarino, S.J., Naficy, A.B., Wierzba, T.F., Abdel-Messih, I., Shaheen, H., Frenck, R.W., Svennerholm, A.M. and Clemens, J.D. 2003. High disease burden of diarrhea due to enterotoxigenic Escherichia coli among rural Egyptian infants and young children. Journal of clinical microbiology, 41, 48624864.

Rashid, M., Kotwal, S.K., Malik, M. and Singh, M. 2013. Prevalence, genetic profile of virulence determinants and multidrug resistance of Escherichia coli isolates from foods of animal origin. Veterinary World, 6 , 139-142.

Read, S., Gyles, C., Clarke, R., Lior, H. and McEwen, S. 1990. Prevalence of verocytotoxigenic Escherichia coli in ground beef, pork, and chicken in southwestern Ontario. Epidemiology and infection, 105, 11-20.

Sharaf, O.M., Gamal, A.I., Tawfek, N.F ,.Effat, B.A., El Shafei, K., El-Din, H.M. and Salem, M.M. 2014. Prevalence of some pathogenic microorganisms in factories Domiati, Feta cheeses and UHT milk in relation to public health sold under market conditions in Cairo. International Journal of ChemTech Research, 6(5): 2807-2814.

Vidal, R.M., Valenzuela, P., Baker, K., Lagos, R., Esparza, M., Livio, S., Farfán, M., Nataro, J.P., Levine, M.M. and Prado, V. 2009. Characterization of the most prevalent colonization factor antigens present in Chilean clinical enterotoxigenic Escherichia coli strains using a new multiplex polymerase chain reaction. Diagnostic Microbiology and Infectious disease, 65, 217-223.

Virpari, P., Nayak, J., Brahmbhatt, M. and Thaker, H. 2013. Study on isolation, molecular detection of virulence gene and antibiotic sensitivity pattern of Escherichia coli isolated from milk and milk products. Veterinary World, 6, 541-545.

Wenneras, C. and Erling, V. 2004. Prevalence of enterotoxigenic Escherichia coli-associated diarrhoea and carrier state in the developing world. Journal of Health, Population and Nutrition, 370-382.

Wetzel, A.N. 2005. Studies in Shiga toxinproducing Escherichia coli O157:H7: determination of factors contributing to the dissemination of Escherichia coli O157:H7 among dairy farms. The Ohio State Universit.

\section{How to cite this article:}

Amin, W.F., E.H. Ahmed, M.S. Embarak, U.H. Abo-Shama, A.G. Thabit and Ismail, S.Y. 2017. Molecular Detection of Enterotoxigenic E. coli in raw Milk and Milk Products. Int.J.Curr.Microbiol.App.Sci. 6(11): 856-864. doi: https://doi.org/10.20546/ijcmas.2017.611.100 